\title{
Fundraising for Stigmatized Groups: A Text Message Donation Experiment
}

KATERINA LINOS University of California, Berkeley

LAURA JAKLI Harvard University

MELISSA CARLSON Stanford University

\begin{abstract}
$A$ s government welfare programming contracts and NGOs increasingly assume core aid functions, they must address a long-standing challenge-that people in need often belong to stigmatized groups. To study other-regarding behavior, we fielded an experiment through a text-to-give campaign in Greece. Donations did not increase with an appeal to the in-group (Greek child) relative to a control (child), but they were halved with reference to a stigmatized out-group (Roma child). An appeal to fundamental rights, a common advocacy strategy, did not reduce the generosity gap. Donations to all groups were lower near Roma communities and declined disproportionately for the Roma appeal. Qualitative research in 12 communities complements our experiment. We conclude that NGO fundraising strategies that narrowly emphasize either in-groups or out-groups, or fundamental rights language, may not be as effective as broader appeals, and we discuss implications for public goods provision in an era of growing nationalism.
\end{abstract}

\section{INTRODUCTION}

A

s government welfare spending declines across much of the Western world, nongovernmental organizations (NGOs) increasingly fund basic

Katerina Linos (D), Professor of Law, University of California, Berkeley, klinos@berkeley.edu.

Laura Jakli (D), Junior Fellow, Society of Fellows, Harvard University, ljakli@fas.harvard.edu.

Melissa Carlson, Postdoctoral Fellow, Center for International Security and Cooperation, Stanford University, melcarl@stanford.edu.

We are grateful to Prolepsis for their extraordinary help in designing, carrying out, and interpreting this study and to all the school principals who agreed to be interviewed. For technical assistance and expertise in geospatial mapping, we thank Stavros-Nikiforos Spyrellis. For extensive comments and suggestions on earlier drafts, we thank K. T. Albiston, Isabelle Cohen, Nadia Dalma, Kevin Davis, John Ferejohn, Vicky Fouka, Stavros Gadinis, Alexandra Hartman, David J. Hendry, Elisabeth Ivarsflaten, Michael Johns, Lewis Kornhauser, Elizabeth Linos, Athina Linou, Aila Matanock, John McCauley, Tom Pegram, Victoria Plaut, Alison Post, Avani Mehta Sood, Laura Stoker, and Chagai Weiss. We also thank the participants of the 2017 APSA Experimental Studies of Racial and Ethnic Prejudice Panel, the 2017 Berkeley Law Faculty Workshop, the 2017 University College London Political Science Department's Research Seminar series, the 2018 APSA Integration, Inclusion, and Ethnic Group Trust: Experimental Analyses Panel, the 2019 ISA Refugees and Migrants Through Social Media Panel, and the 2019 NYU Law and Economics Workshop. We thank our three anonymous reviewers for their careful reading of our manuscript and their insightful feedback. For their generous support, we thank the Carnegie Foundation, Berkeley Law's Miller Center for Global Challenges and the Law, the Jean Monnet Program, and the German Academic Exchange Program. The project has been approved through U.C. Berkeley IRB protocol \#2016-03-8553. Replication materials at available at the American Political Science Review Dataverse: https://doi.org/10.7910/DVN/2XO7HR.

Received: January 10, 2019; revised: May 26, 2020; accepted: July 31, 2020 . social needs (Ball 2007; Diller 2001; Korpi and Palme 2003; Linos and West 2003). However, unlike governments, which can compel contributions, NGOs must persuade donors to give. NGOs thus face a particularly acute trade-off between effective aid programming and sustainable financing (Belcher and DeForge 2012; Kogut and Ritov 2011). When they seek donations for narrowly tailored programs, NGOs optimize service delivery to the groups most in need, but the stigma associated with these groups may greatly reduce donations.

Many NGOs are aware of these trade-offs. In response, some exclude the most stigmatized from their programming, as in the case of HIV prevention programs that exclude persons who contracted the virus through sexual activity (Amirkhanian et al. 2004) or anti-poverty efforts that leave out the "ultra-poor" in Bangladesh (Matin and Hulme 2003). More commonly, NGOs make in-group appeals by emphasizing shared characteristics between donors and recipients, such as religion, ethnicity, language, or community membership (Koch et al. 2009). For example, NGOs commonly refer to potential aid recipients by names that signal membership in the dominant ethnicity, race, or religion (Kogut and Ritov 2007).

In contrast, other NGOs try to increase out-group generosity by making universalistic appeals to human rights, hoping that these appeals will underscore recipient need and shift cognitive representations of out-group members from "an 'us' versus 'them' orientation, to the more inclusive 'we' orientation" (Scroggins et al. 2016, 220). For example, UNICEF's donation webpage emphasizes that "Every child has the right to learn" (UNICEF 2020). Similarly, advocates for the Roma in Europe have used the language of human rights to increase out-group altruism for over two decades (Cortes 2015). 
Since we do not fully understand how ethnic diversity shapes generosity, it is unclear whether in-group appeals, appeals to universal rights, or other strategies increase donations and how sizeable the trade-offs of each strategy might be. Numerous observational studies suggest that diverse communities provide less funding for public goods than homogenous ones (e.g., Alesina and La Ferrara 2000; Stichnoth and van der Straeten 2013). However, they may overstate the effect of ethnic heterogeneity because minority communities suffer from multiple disadvantages (including less wealth, weaker institutions, and weaker social trust) for which observational research cannot fully control (Lee 2018; Singh and vom Hau 2016).

Over the last few decades, the field has reoriented toward experimental research to examine intergroup dynamics with higher internal validity. However, even the best designed lab and lab-in-the-field experiments raise external validity concerns. For instance, they often involve researcher money and subjects who know they are being observed, which can lead scholars to overestimate generosity and underestimate prejudice (Harrison and List 2004). Moreover, because experiments are typically fielded in one or few sites, they cannot assess intergroup behavior across varied institutional and geographic contexts. The strongest field experiments unobtrusively vary the ethnicity of job applicants, loan applicants, and service providers, and examine the magnitude of real-life responses by employers, lenders, and customers who are unaware that they are being observed (e.g., Adida, Laitin, and Valfort 2010; Ayres, Vars, and Zakariya 2004; Banerjee 2008; Booth, Leigh, and Varganova 2012).

We build on this tradition of unobtrusive field experiments by studying, for the first time, ethnic biases using an increasingly common fundraising tool: the text to-give campaign. In these campaigns, individuals typically make small financial donations to NGOs through a text message (Smith 2012). Following the 2010 earthquake in Haiti, when the Red Cross raised over $\$ 43$ million in text donations, charities worldwide adopted text-to-give fundraising (Smith 2012).

Because our technique allows us to field the same experiment in hundreds of communities, we also build on research suggesting that context influences intergroup interactions and generosity (e.g., Condra and Linardi 2019). Intergroup generosity is likely highest when groups have equal status and institutions support integration (Alexander and Christia 2011). According to contact theory, frequent intergroup interaction increases public goods provision in these contexts (e.g., Allport 1954; McLaren 2003; Pettigrew 1998). In contrast, according to racial threat theory, unstructured intergroup interaction can increase conflict and reduce public goods provision (e.g., Adida, Laitin, and Valfort 2016; Enos 2014). However, little is known about contexts in which ethnic groups rarely interact due to de jure or de facto segregation-despite the fact that segregation poses acute challenges for policy makers.

We focus on fundraising for the Roma because they are Europe's most isolated and persistently poor ethnic minority (EU-MIDIS II 2016) but are understudied
(Bracic 2016). In the nine EU states with the largest Roma populations, $80 \%$ of the Roma live in poverty and a third live in households that lack basic amenities, such as running water (EU-MIDIS II 2016, 9). Although $80 \%$ of Europe's Roma are sedentary and commonly reside in long-standing segregated communities, they are stereotyped as transient beggars lacking work ethic (Cretan and Powell 2018; Matras 2015). Attitudinal measures of discrimination indicate that roughly half as many Eurobarometer survey respondents are comfortable working with the Roma out-group $(46 \%)$ as with the Greek in-group (93\%) (European Commission 2015). While expressed prejudice toward other vulnerable groups decreased across the EU over the last decade, expressed prejudice toward the Roma remains consistently high. Figures I.1-I.3 in Appendix I further illustrate these patterns and underscore how few Europeans have Roma friends or acquaintances.

We embedded an unobtrusive, large-scale field experiment in a text-to-give campaign in Greece. We partnered with a local NGO that serves free lunches in public schools to request a small but nontrivial charitable contribution to their school lunch program (1.5 euro $[<\mathrm{US} \$ 2])$. We randomly varied the donation request in a three-by-two factorial design. In one condition, we made an explicit in-group appeal (ethnically Greek child), in another condition we made an explicit out-group appeal (Roma child), and in the control condition we referenced a child. ${ }^{1}$ We also varied whether we included an appeal to universal rights.

We found that the in-group appeal did not increase generosity relative to the control, whereas the outgroup appeal halved donations. In contrast to a large literature that assumes the efficacy of in-group appeals, by including a control, we found that the generosity gap was driven by individuals' negative reaction to the outgroup (Roma) appeal. We also found that an appeal to universal rights neither influenced donation magnitude nor reduced the ethnic discrepancy in generosity. This suggests that human rights language may not increase altruism. Finally, we examined whether geographic proximity to out-group beneficiaries influences the effectiveness of in-group and out-group donation appeals. Whereas on average, donations fall by $50 \%$ when the Roma out-group is referenced, near informal Roma communities, the donation gap reaches $70 \%$.

To better understand how NGOs solicit donations when expressed prejudice is high and assess the nature of intergroup contact in highly segregated settings, we complemented our experiment with qualitative research. Expecting positive intergroup contact to be most frequent in schools, we interviewed principals in 12 elementary schools with Roma comprising 3-100\% of students. We find that statements stigmatizing the Roma are commonplace and social contact with ethnic Greek neighbors is limited, even in the most integrated communities. While three principals received in-kind

\footnotetext{
${ }^{1}$ The vast majority of Roma in Greece are Greek citizens; throughout this study we use the term "Greek" to refer to ethnicity, not nationality.
} 
support from local fundraising efforts, all 12 reported that more significant donations came from national and European governmental and nongovernmental sources.

To conclude, we argue that NGOs may benefit from employing broad-based fundraising appeals that go beyond local donor pools. We also suggest that emphasizing need, rather than rights, may be particularly effective for programming that benefits highly stigmatized groups. We describe how discrimination theories extend to segregated settings, and in the absence of local contact, national narratives may be disproportionately important. Lastly, we discuss how scholars can use text message experiments to assess, with high internal and external validity, theories of other-regarding preferences across varied geographic and institutional contexts.

\section{FUNDRAISING IN DIVERSE COMMUNITIES: UNDERSTANDING THE GENEROSITY GAP}

Extensive scholarship suggests that ethnically diverse communities have much lower funding for public goods and welfare programs (e.g., Hopkins 2011; Stichnoth and van der Straeten 2013). For example, greater ethnic diversity is associated with reduced support for welfare spending in the United States (Luttmer 2001), with lower contributions to local organizations and public services in Indonesia (Okten and Osili 2004), and with lower primary school funding in Kenya (Miguel and Gugerty 2005). Even in universalistic Nordic welfare states, exclusionary attitudes have increased with higher rates of immigration (Larsen and Dejgaard 2013; van der Waal et al. 2010). Scholars have identified various mechanisms that drive these patterns, including a preference for the welfare of one's in-group (Tajfel 1974; Vigdor 2004), greater trust and stronger reciprocity norms within ethnic groups (Alesina and La Ferrara 2002; Habyarimana et al. 2007), and the impulse to impose invasive social controls on outgroups (Eitle and Turner 2002).

As aid organizations' role in public service provision expands, they must decide whether to include stigmatized groups in their programming, and if so, how to fundraise for them (Kogut and Ritov 2011). Some emphasize shared in-group characteristics in their appeals, such as religion, geography, or nationality. According to the charitable giving literature, referencing in-group membership strengthens perceived social ties and reinforces a sense of duty to contribute (Bohm, Rusch, and Gurek 2016; Corr et al. 2015; Halevy, Bornstein, and Sagiv 2008; Koch et al. 2009). An extreme application of this strategy can lead NGOs to explicitly exclude stigmatized out-groups. For example, certain NGOs that work to reduce interethnic tensions in Romania, Hungary, Slovakia, and Ukraine systematically exclude the Roma from their programming (Stroschein 2002). Other NGOs use the language of fundamental rights to emphasize recipient need or to expand in-group membership to include minorities. Initially used to combat race and gender discrimination (Bob 2007; Lerche 2008), human rights appeals are now widely used by advocates for the disabled, for migrants and refugees, and for the LGBTQ community, among others (Bloemraad, Silva, and Voss 2016).

However, theoretical ambiguities and methodological limitations leave us unclear on which strategies are more effective in different contexts. First, the literature is unclear on the magnitude of the intergroup generosity gap. Since heterogeneous communities often suffer from multiple disadvantages, observational studies may overstate the effects of in-group favoritism and out-group bias (Lee 2018; Singh and vom Hau 2016). Indeed, the most robust observational studies - natural experiments - do not find that an increase in out-group presence reduces support for social welfare (Gerdes 2011). In contrast, lab and lab-in-the-field studies may overestimate generosity and underestimate bias because subjects behave in socially desirable ways when observed and when using researcherprovided funds (Harrison and List 2004). By designing an unobtrusive intervention through a popular fundraising technique, we minimize respondents' desire to appear altruistic (Scacco and Warren 2018; Zizzo 2010). Our study assesses how a broad range of ordinary individuals make snap judgments that might be driven by subconscious bias.

Second, although it is well established that giving is higher to in-groups than to out-groups, causal mechanisms remain unclear. For example, many studies report a single in-group/out-group donation differential, which makes it unclear whether in-group favoritism or out-group bias - or a combination of the two-drives the generosity gap. We solicit donations to an in-group, to an out-group, and to a control group, and allow for the possibility that donations to all groups could go up or down simultaneously. Additionally, we do not know whether commonly made appeals to fundamental rights increase donations to out-group members. Our experimental design allows us to more sharply assess these mechanisms.

Third, existing scholarship is unclear on which contexts reduce the generosity gap. Even state-of-theart experiments typically capture other-regarding preferences in narrow geographic regions, leaving some uncertainty about how institutional and geographic context shape the experimental results (e.g., Alexander and Christia 2011; Condra and Linardi 2019). Two recent lab-in-the field experiments have moved the literature forward by employing multiple study sites to examine intra-Jewish cleavages and JewishPalestinian discrimination (Enos and Gidron 2016; 2018), but the geographic range of our experiment is unparalleled, as Figures 1 and 3 show.

Finally, the context of ethnic segregation is undertheorized, as studies predominantly focus on positive and negative intergroup contact, rather than on the absence of contact. Some studies focus on structured and extensive contact among groups of equal status in institutions that support integration, such as schools (Alexander and Christia 2011). In such contexts, contact theory suggests that increased intergroup 
interaction improves cooperation, promotes the formation of reciprocity norms, and increases public goods provision (e.g., Allport 1954; Brown and Hewstone 2005; McLaren 2003). Other work examines contexts in which contact is frequent but casual and involuntary, such as riding on commuter transit or waiting in line (Condra and Linardi 2019; Enos 2014). Here, the racial threat hypothesis posits that dominant groups develop exaggerated fears of economic, political, and criminal threats posed by large minority populations and that unstructured contact highlights intergroup differences in physical and cultural attributes (e.g., Adida, Laitin, and Valfort 2016; Brewer and Gaertner 2003; Condra and Linardi 2019; Eitle and Turner 2002; Enos 2014). However, some stigmatized communities have limited contact with others, including long-standing segregated ethnic and religious minorities like the Dalit in India (Bob 2007), the Rohingya in Myanmar and Bangladesh (Kipgen 2013), and Uyghur Muslims in China (Caprioni 2011).

In the sections below, we develop and test theoretical claims to better assess the magnitude of the in-group and out-group generosity gap, explore the causal processes that drive this gap, and systematically explore variation in context.

\section{HYPOTHESES ON INTERETHNIC GENEROSITY, RIGHTS APPEALS, AND OUT-GROUP PROXIMITY}

In this section, we develop hypotheses on three major debates: (a) the extent to which in-group preference or out-group bias drives the interethnic generosity gap, (b) whether universal rights appeals reduce this gap, and (c) how geographic proximity to a minority group influences this gap.

The charitable giving literature suggests that referencing shared group membership creates a sense of mutual obligation between donor and beneficiary (Bohm, Rusch, and Gurek 2016; Corr et al. 2015; Halevy, Bornstein, and Sagiv 2008; Koch et al. 2009). Many NGOs use in-group appeals to boost donations by emphasizing that beneficiaries belong in the donors' geographic, ethnic, or religious community. They also curate their advertising to ensure that beneficiaries with names and physical attributes typical of the majority group are featured. Experiments support the intuition that in-group appeals are more effective than out-group ones. For example, in a series of donation experiments, wealthy and educated Indians were less likely to donate to individuals with names that signified they were Dalit or from a scheduled caste (Deshpande and Spears 2016). Similarly, emphasizing a common Muslim identity reduced Turkish citizens' prejudice against Syrian refugees on attitudinal survey measures (Lazarev and Sharma 2017) and appealing to a common German identity reduced intergroup conflict between East and West Germans in longitudinal surveys (Kessler and Mummendey 2001).

What is less clear from existing empirical work is whether in-group favoritism, out-group prejudice, or a combination, drive observed gaps in giving. We examine other-regarding behavior-that is, behavior that benefits others despite the lack of material incentives to do so (Persico and Silverman 2006). Other-regarding behavior, including making donations, is not zero-sum. Because it is possible to increase (or decrease) benefits to the in-group and out-group simultaneously, it is important for fundraisers to understand what drives the generosity gap.

Distinguishing between in-group favoritism and outgroup bias is also important to a broader literature on interethnic relations, as different mechanisms can drive the two. Scholars argue that individuals may be more generous to other in-group members due to higher social trust in one's own ethnic group (Alesina and La Ferrara 2002), a shared cultural understanding that speeds up group communication (Hardin 1995), or greater similarity in public goods preferences among in-group members (Miguel 1999). A series of lab-inthe-field experiments find that in-group favoritism emerges in repeated games where players can establish in-group reciprocity norms and better sanction ingroup violators (Habyarimana et al. 2007). Individuals may also derive greater utility from the welfare of in-group members because they link in-group welfare to their own (Tajfel 1974; Vigdor 2004).

In contrast, others argue that individuals may be less likely to give to out-group members due to perceived competition for resources and economic threat (Bobo 1983; Quillian 1995) and seek to impose social controls on out-groups so as to maintain the status quo (Eitle and Turner 2002; King and Wheelock 2007). Conversely, social identity theory suggests that in-groups may be biased against the out-group even in the absence of meaningful competition over resources, meaning that enmity is more a function of strong psychological predispositions than of rational utility (Kinder and Sears 1981). For example, the dominant group may feel distaste stemming from assumptions that out-groups violate rules of reciprocal exchange (Cottrell and Neuberg 2005).

In the Greek context, we expect the ethnic majority to respond generously to in-group appeals but poorly to out-group appeals. This is because donations depend heavily on whether recipients are believed to be at fault for their poverty (Fong and Luttmer 2011; Henry, Reyna, and Weiner 2004). Greek media typically portray the Roma as persistently poor and undeserving. Moreover, prejudice toward the Roma has been stable in public opinion surveys for a decade (see Appendix I, Figure I.1). In turn, we expect the differential between donations in the Roma treatment and the control to be stable. Attitudes toward the in-group should also be relatively stable, although we expect the external events when we fielded our experiment-namely, EU austerity measures and the influx of asylum seekers - to increase the resonance of the in-group treatment (Linos 2003; Sambanis, Schultz, and Nikolova 2018).

Unlike prior studies, which compare donation differentials between in-group and out-group appeals, we disaggregate in-group preference from out-group bias by introducing a control condition. Our study 
design, which employs a neutral control condition ("child") in addition to the in-group condition ("Greek child") and out-group condition ("Roma child"), allows us to test three hypotheses about the differential impact of in-group and out-group appeals on donations:

H1A: Individuals respond more generously to an in-group appeal than to an out-group appeal.

H1B: Individuals respond more generously to an in-group appeal than to an appeal that does not invoke shared ethnicity.

H1C: Individuals respond less generously to an out-group appeal than to an appeal that does not invoke differing ethnicity.

When NGOs explicitly mention stigmatized outgroups in their donation appeals, they often use the language of fundamental rights to counter the effects of prejudice. For example, one Islamic charity group emphasizes that "everyone has the right to water" on their donation page (Muslim Aid 2020). Humanitarian practitioners and rights advocates have long used universal human rights appeals to boost support for stigmatized groups, including women (Reilly 2007), ethnic minorities (Cortes 2015; Morrison, Plaut, and Ybarra 2010), different castes (Bob 2007; Lerche 2008), migrant workers (Basok and Carasco 2010; Sim 2003), and refugees (Bloemraad, Silva, and Voss 2016).

Fundamental rights appeals can highlight recipient need by signaling that core rights to food, education, and housing are not being met. According to the literature, this approach is effective because people behave more altruistically when they are made aware of outgroup needs (Batson, Lishner, and Stocks 2015). In addition, appeals that emphasize out-group deservingness of certain protections and resources have been shown to increase various forms of out-group support (Bekkers and Wiepking 2011; Hafer 2011).

Appeals to universal human rights can also broaden in-group membership by making salient individuals' shared human or global identity (Nickerson and Louis 2008), leading them to evaluate out-group members more positively and with greater empathy (Buchan et al. 2011; Kessler and Mummendey 2001; Reysen and Katzarska-Miller 2013)-ultimately, increasing support for their rights (McEntire, Leiby, and Krain 2015; McFarland, Webb, and Brown 2012; Reese, Proch, and Finn 2015).

Some survey and lab experiments on donations suggest that appeals to broader social values (e.g., human rights) can reduce ethnic discrepancies (Gaertner and Dovidio 2014). Other studies report that support for torture declines (Chilton and Versteeg 2015; Wallace 2013), while support for health and labor rights (Linos 2011;2013) increases when the language of fundamental rights is made salient to survey respondents. However, other survey experiments report null results (Bloemraad, Silva, and Voss 2016). It remains unclear whether human rights appeals can shift altruism toward out-groups in realworld contexts. Behavioral evidence is especially limited with regard to extremely stigmatized outgroups. Therefore, we use our field experiment to test the following hypothesis:

H2: Universal rights appeals will increase individuals' willingness to support out-group members, reducing the generosity gap between the in-group and out-group.

Finally, we examine how geographic proximity to a minority group affects giving. Contact theory suggests that increased intergroup interaction may improve cooperation, promote the formation of reciprocity norms, and increase public goods provision (e.g., Allport 1954; Brown and Hewstone 2005; McLaren 2003). However, since few institutions facilitate meaningful Roma integration, the Greek context fails to meet the scope conditions for contact to manifest in positive intergroup relations.

Alternatively, variants of the racial threat hypothesis suggest that dominant groups develop exaggerated fears of economic, political, and criminal threats posed by large minority populations and that ethnic distinctions increase in heterogeneous communities (e.g., Brewer and Gaertner 2003; Eitle and Turner 2002). The strongest evidence of racial threat is found in communities characterized by casual, non-institutionalized, and involuntary interethnic contact. For example, Enos (2014) exposed whites to Spanish-speaking Latinos during their daily commutes and found an increase in whites' support for exclusionary immigration policies toward Mexicans. Adida, Laitin, and Valfort (2016) found that increasing the presence of Senegalese Muslims in a dictator game decreased French interethnic donations. Condra and Linardi (2019) found that day workers in Afghanistan donated more to in-group members when out-group members were physically present. According to the logic of racial threat, unstructured contact highlights intergroup differences in physical and cultural attributesleading to conflict and a reduction in public goods.

Since the Roma in Greece are strongly disliked and highly isolated in densely populated communities, we initially expected that their presence would produce an extreme version of racial threat. However, certain features of ethnic Greek-Roma relations make the application of racial threat theory less straightforward. The theory of racial threat was developed by studying race relations in the United States (Wagner et al. 2006). The racial threat literature highlights minority size and economic competition as necessary conditions for threat to manifest (Wetts and Willer 2018). However, it is unclear from this literature how threat manifests near isolated Roma communities, since they are not in meaningful competition with ethnic Greeks for economic or social status.

Because our study was large and fielded across a broad range of communities, we are able to replicate 
the methodology of prior observational studies that examine whether donation rates decline near minority communities. In addition, however, we can experimentally examine whether donations near minority communities decline disproportionately for the Roma outgroup. Also, we can look for across-the-board declines in giving near minority communities, because ethnic heterogeneity may lower trust and cause donations to decline both to the in-group and the out-group (Putnam 2007) or because measures of poverty and other control variables imperfectly capture the many disadvantages from which minority communities suffer. Therefore, our third hypothesis has two variants:

H3A: Geographic proximity to a stigmatized out-group (Roma) reduces donations to this out-group disproportionately.

H3B: Geographic proximity to a stigmatized out-group (Roma) reduces donations to all groups.

It is possible that not all Roma communities prompt a racial threat response in neighboring ethnic Greeks. In particular, very small Roma communities may go unnoticed by the local population. This would be consistent with empirical work on racial threat theory in other contexts (Fossett and Kiecolt 1989; Jackson 1986; Wetts and Willer 2018).

In addition, levels of spatial Roma integration and group visibility vary. The poorest and most segregated Roma live in informal communities, in makeshift housing that include informal huts that lack running water and proper insulation. There are also large Roma populations that live in segregated neighborhoods, but in apartment buildings that are comparable to those of lower and even middle-class ethnic Greeks. Finally, some Roma families are fully integrated and live in predominantly Greek neighborhoods. We expect ethnic Greeks to express the strongest negative sentiments toward informal Roma settlements due to their visibly dilapidated housing and the signals this sends about social and cultural differences.

One other major factor may influence out-group generosity in highly segregated settings. Unlike in moderately segregated settings, there may be very limited meaningful social contact. It is possible that in-group members - both proximate and distant - rely on the same national cultural narratives to shape their thinking about out-group deservingness. The influence of a national narrative may bias our experiment against finding localized evidence of racial threat. We investigate these varied possibilities in the sections that follow.

\section{A NATIONWIDE TEXT MESSAGE DONATION EXPERIMENT}

This experiment was carried out in coordination with a Greek NGO and a text messaging company that operates with the three major mobile carriers in Greece.
Text-to-give campaigns are common in Greece, in part because the major phone carriers provide registered NGOs with three opportunities a year to fundraise using text donation requests. This feature of Greek charitable giving allows us to study intergroup relations by unobtrusively observing the outcome of a seemingly ordinary request for donations.

The experimental design followed a three-by-two factorial, yielding six different texts requesting a small financial donation to the Diatrofi Program, which provides free lunch to Greece's poorest public schools, and does not focus on any specific ethnic group in its programming. Text recipients assigned to the control group received a message stating, "Diatrofi feeds 16,412 students. Text DIATROFI to 54344 for one child in need. 1.48 Euro per SMS." The first treatment dimension randomized between a Roma child $(\pi \alpha i \delta i$

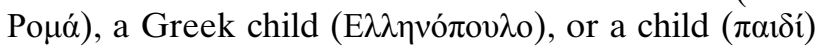
with no ethnic specification. The language we used for "Greek child" is commonplace and not anti-Roma; it has subtle nationalist and in-group connotations. The second treatment dimension varied whether the text included a rights appeal. Half of the messages added the statement: "Every child has a right to food." In sum, the experiment has a 3 (child background: Roma child/ Greek child/child) $\times 2$ (human rights appeal: present/ absent) factorial between-subjects design. For additional details on question wording, IRB approval, compliance with Greek legislation, and study preregistration, see Appendix IV.

Our nationwide SMS experiment was administered from March 24th to March 28th, 2016. The study subjects are adults living in Greece who are customers of one of three mobile carriers and consented to receiving texts requesting donations from licensed NGOs at the time of initializing service. They also agreed to have broad, unidentifiable aggregate data disclosed, including their age, gender, and zip code. Unfortunately, this provides our analysis with few covariates. However, because zip codes in Greece are small, with only 7,100 inhabitants on average, we can infer certain demographic characteristics from zip code level data with reasonable accuracy.

A total of 79,368 individuals spread across 1,051 Greek zip codes were sent one of these treatments. The average SMS recipient was 40 years old. The subject pool skewed male $(65 \%$ men; $35 \%$ women). A total of $42 \%$ of the study subjects reside in Attica, which encompasses Athens and its vicinities, and in which almost half of the Greek population lives; another 19\% reside in Central Macedonia, a region that contains Greece's second largest city, Thessaloniki (Hellenic Statistical Authority 2014). The zip code level median individual income was 7,342 Euro, while the average child poverty rate was $29 \%$. A total of $25 \%$ of persons sent messages live in a zip code with Roma communities totaling at least 100 residents, and $18.6 \%$ live in zip codes that include informal Roma communities in particular. ${ }^{2}$

\footnotetext{
2 There is some measurement error in the zip code of SMS recipients because some may have moved since purchasing their SIM cards.
} 
The SMS company implemented the randomization; Appendix II, Tables II.1-II.4 illustrate that the randomization was successful. Approximately $60 \%$ of messages $-47,887-$ were reportedly received. The rest were sent to numbers that were no longer valid or were unable to receive messages at the time these were sent. Based on our consultations with the SMS company, messages were likely not delivered because many numbers were out of date. Residents of Greece change phone numbers frequently because new SIM cards often come with special offers; indicatively, Greece has 116 mobile phone subscriptions per 100 inhabitants (World Bank 2018). There is no reason to believe that "dead" phone numbers are related to treatment assignment, which would induce post-treatment bias (Coppock 2019). We therefore conduct an intent-totreat analysis.

In total, Prolepsis received 510 Euros in donation via SMS from 291 respondents. Respondents could reply to the text message multiple times; each respondent donated between 1.5 and 15 Euros, averaging 1.75 Euros in donation per donor. Our $0.6 \%$ response rate 3 for a single received text message is in line with response rates reported by other researchers making a one-time unsolicited donation request (Damgaard and Gravert 2017). These response rates are generally low, ranging from face-to-face canvassing with an $8 \%$ average response rate, to volunteer phone calls with a $3 \%$ average, to commercial phone calls with a $0.6 \%$ average, to direct mail campaigns with a $0.6 \%$ average (Dale and Strauss 2009; Ha and Karlan 2009; Nickerson and List 2007). The economic and migration crises in Greece may have contributed to donor fatigue, depressing donations (Eckel, Grossman, and Milano 2007).

An important caveat of our research design is that we lack data on ethnicity. However, the Greek context allows us to maintain the assumption that respondents are ethnic Greeks, because Greece has a single preeminent ethnic majority, and the Roma constitutes a very small and impoverished minority. This makes it unlikely that the Roma would be overrepresented among persons receiving text messages or donating. Subsequent analyses show that donations are below average near Roma communities, which Appendix III, Table III.1 confirms. Additional analyses in Appendix III, Table III.1 demonstrate that donors are more likely to be women, and live in wealthier communities, consistent with the donation literature (Shier and Handy 2012; Winterich, Mittal, and Ross 2009).

As an additional check, Figure 1 maps where donations originated. We see that donations are geographically dispersed across regions with various economic levels. As expected, many donors reside in major metropolitan areas such as Athens and Thessaloniki, which are the most densely populated areas of Greece and have above-average income levels (Hellenic Statistical Authority 2014). The map also shows that

\footnotetext{
${ }^{3}$ Note that the $0.6 \%$ response rate is calculated using the 47,887 SMSs received as the denominator; it falls below $0.4 \%$ if we include all messages sent (received and not received).
}

Thrace - a poor region bordering Bulgaria and Turkey where a Muslim minority resides - is not heavily represented among donors.

\section{OUT-GROUP BIAS AND PROXIMITY DEPRESS DONATIONS TO THE ROMA}

Our experimental analysis provides an internally and externally valid measure of the generosity gap between the ethnic majority and the stigmatized Roma population. We also assess the extent to which this donation gap is driven by in-group preference, out-group bias, or both; whether universal rights appeals narrow this gap; and how geographic proximity influences donation patterns.

We find that the in-group appeal was no more effective in generating donations than the control. When the appeal specified a Roma child as the aid recipient, donations were halved. A human rights appeal did not narrow this donation gap. Figure 2 presents these results through a logistic regression model that predicts the probability of donation as a function of treatment assignment. The results are presented as a simple intent-to-treat analysis. The full logit model can be found in Appendix II, Table II.5. Our findings do not depend on the inclusion or exclusion of controls or on the functional form of our regression, as the robustness checks in Appendix II, Figure II.1 and Table II.5 show.

Our data indicate that, relative to the out-group appeal, the in-group appeal and control more than doubled the probability of donation from a $0.22 \%$ to a $0.45 \%$ average donation rate. This finding is statistically significant and consistent with hypothesis $1 \mathrm{~A}$, which predicts that text recipients will respond more generously to an in-group appeal than to an outgroup one.

Without a control group, evidence of hypothesis $1 \mathrm{~A}$ could be interpreted as in-group preference for ethnic Greeks. However, we find no support for hypothesis 1B: no significant differences emerge when we reference the control group "child" as opposed to the in-group "Greek child" in the text message. Contrary to large literatures, our experimental results indicate that naming the in-group does not trigger a sense of shared purpose or invoke a duty to contribute among Greeks. One caveat in our research design is that some respondents may have assumed that the "child" invoked in the control condition was an ethnically "Greek child." However, even if some respondents consider their in-group the baseline category, the literature's emphasis on in-group ties leads us to expect that an explicit in-group reference would generate at least some additional giving. The context of our study supports the same expectation; we fielded the text experiment at the height of the refugee crisis in March 2016, when Greek ethnicity was particularly salient (Carlson, Jakli, and Linos 2017; 2018).

Consistent with hypothesis $1 \mathrm{C}$, Greeks responded less generously to an out-group appeal than to an appeal that does not invoke ethnicity. Donations were more than 


\section{FIGURE 1. Map of Donations and Income Distribution across Greece}

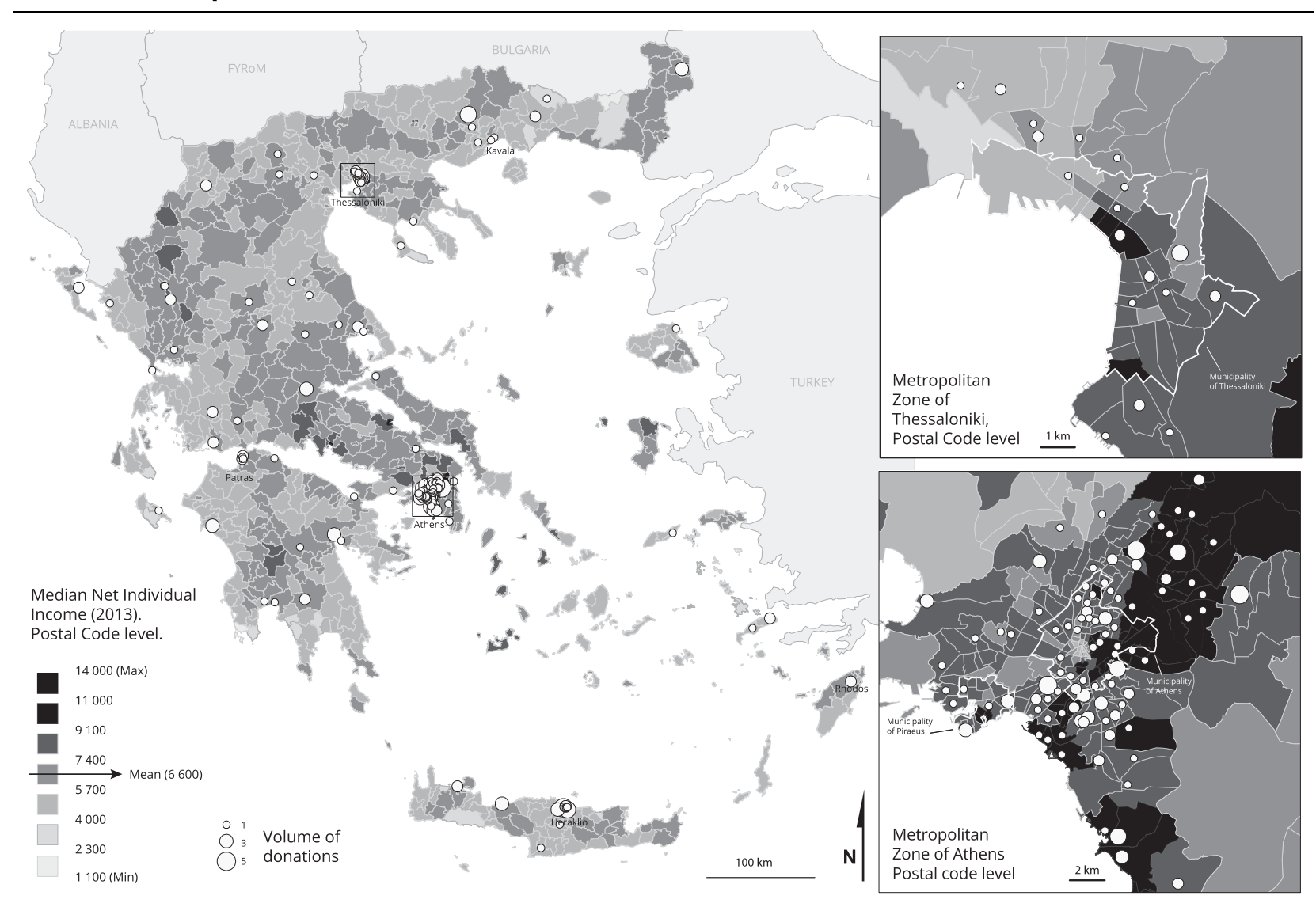

Note: This figure employs median net individual income data at the zip code level from the Greek Economics Ministry (2013); donations are proportional to their amount.

halved in the out-group appeal relative to the control. This finding is statistically significant and consistent with our expectation that out-group bias and social stigma depress generosity toward the Roma in Greece. The magnitude of this drop is robust to different model specifications (see Appendix II, Table II.5).

Figure 2 also demonstrates that the rights appeal does not reduce the generosity gap, contrary to hypothesis 2. Additional checks (in Appendix II, Table II.5) demonstrate that the substantively small differences between the Greek child/Greek rights, child/child rights, and Roma child/Roma rights frames are never statistically significant. This result is inconsistent with numerous prior studies that advocate the use of human rights language to counter the effects of out-group stigma. However, our null result is consistent with two recent experimental studies on rights language fielded in California and Norway (Bloemraad, Silva, and Voss 2016; Ivarsflaten and Sniderman 2017). It is possible that the unobtrusive nature of the SMS experiment removed demand effects and other threats to validity that could inflate the efficacy of human rights appeals in prior work.

Our third hypothesis concerns the effect of geographic proximity to the Roma on donations. We worked with Roma associations to obtain, geocode, and validate a detailed dataset on the location of Roma communities in Greece. This data contains information on two typical Roma configurations, namely settlements and neighborhoods, population estimates for each, and important variables on the condition of the housing structures and their locations relative to city limits. Typically, Roma neighborhoods are comprised of formal housing structures (houses and apartments), while informal communities (typically settlements) are comprised of informal housing structures (huts or movable construction). As Figure 3 illustrates, we aggregated this information at the zip code level. Notably, some Roma families reside outside of these communities in neighborhoods that are not primarily Roma. We believe out-group biases and racial threat stem from exposure to more concentrated Roma communities, so our dataset offers an appropriate test of Roma proximity for hypothesis 3 .

Figure 4 demonstrates that text message recipients were less likely to donate to all treatments when they lived in zip codes with informal Roma communities exceeding a total population of 100 residents. $^{4}$

\footnotetext{
${ }^{4} 18.6 \%$ of SMS recipients are proximate to the out-group using this indicator.
} 
FIGURE 2. Predicted Probability of Donation by Treatment Condition (with $95 \% \mathrm{Cls}$ )

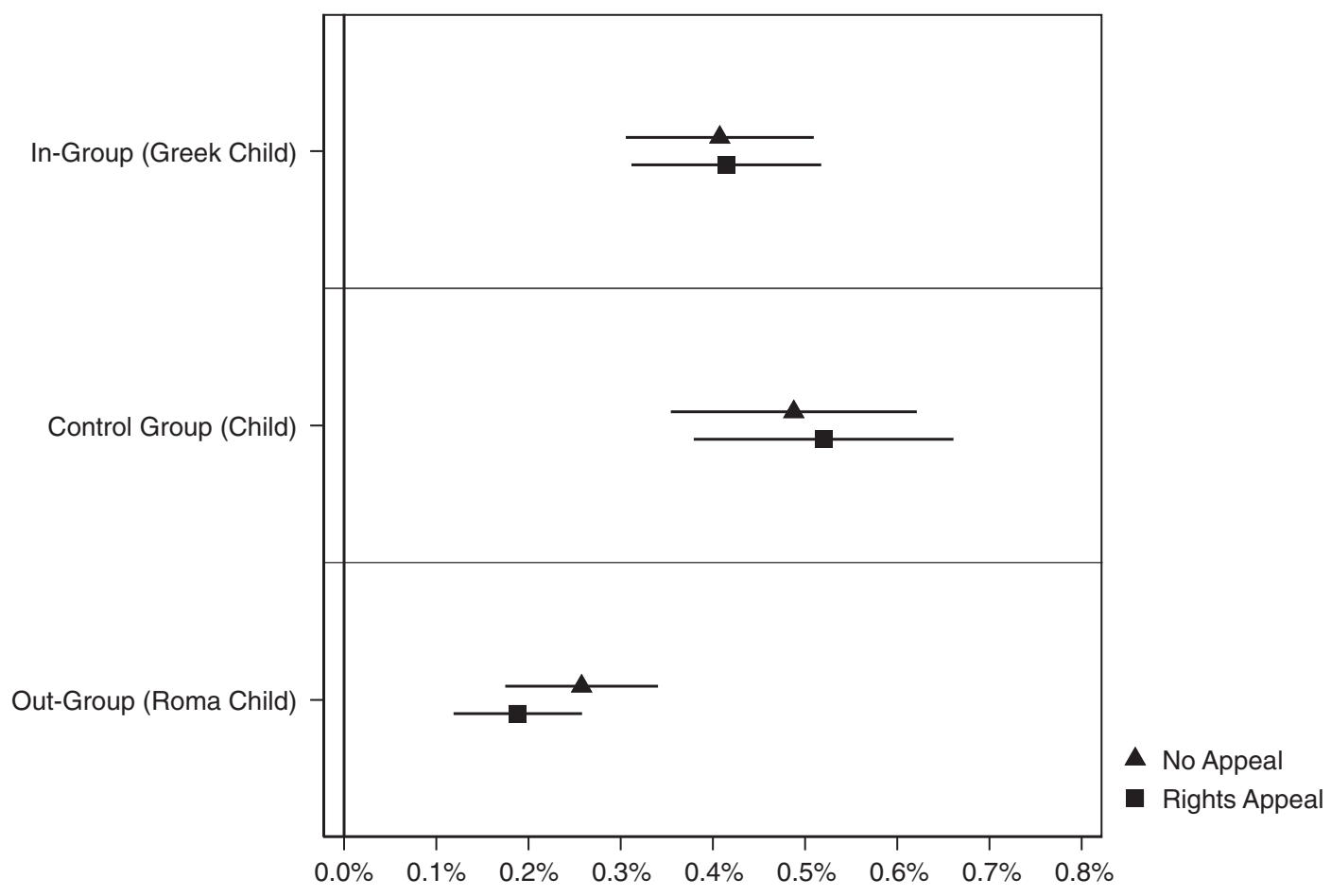

Note: Logistic regression predicting donation based on treatment condition, presented in a simple intent-to-treat format without covariate adjustment. To see that these findings are robust to the addition of standard controls and to other model specifications, see Appendix II, Figure II.1 and Table II.5.

However, the decline in donations to the Roma appeal is disproportionate. Far from Roma communities, donations to the Roma are $50 \%$ lower than to the other treatments. Meanwhile, this donation differential is $70 \%$ in zip codes with informal Roma communities of 100 or more people.

To probe the robustness of this pattern, in Appendix II, Figure II.4, we calculate the contrasts of the predictive margins at nine population thresholds (50-250 Roma population) and find that when 75 or more Roma reside in a zip code, there is a disproportionate drop in donations to the Roma treatment (relative to the in-group or the control). The presence of very small communities (below 75 Roma) does not trigger racial threat. This pattern is consistently significant at the $90 \%$ level or above for all Roma communities, and is consistently significant at the $95 \%$ level when we subset to zip codes that include informal Roma communities, which are the most visible and isolated (see Appendix II, Figure II.4).

Our experiment's three-by-two factorial design allows us to contribute to a large observational literature that observes declines in generosity to outgroups, but it also distinguishes between a general decline in donations to all groups (which we also observed) and a greater, targeted decline that only occurs in the Roma treatment condition. Our experimental results are more consistent with hypothesis $3 \mathrm{~A}$ than 3B. Even in the absence of meaningful intergroup contact, we find evidence that proximity to Roma communities - especially those living in visibly dilapidated housing-disproportionately decrease outgroup generosity.

Our study - like all studies - cannot fully control for the non-random geographic assignment of minority populations. Roma communities and other concentrated minorities are situated in poorer-than-average communities (a measure we and other scholars include in regressions) and also in communities with lower social capital (a measure that we and other scholars do not observe). Even when we control for the most plausible confounders, such as income, poverty rates, city size, and regional variations, other unobserved (and perhaps unobservable) differences may persist. ${ }^{5}$ Thus, there are many ways to interpret the across-theboard reduction in donations near Roma communities. That said, these mechanisms suggest that NGOs should design fundraising campaigns that have broader geographic scope and include more advantaged communities.

However, given our experimental design, we are confident that a significant portion of the decline in donations near Roma communities is due to hostility toward the Roma. We thus add an important experimental test to a largely observational literature on the

\footnotetext{
${ }^{5}$ A particular concern is that text messages are less likely to be delivered in underprivileged communities if persons change SIM cards more frequently to benefit from promotions.
} 


\section{FIGURE 3. Map of Zip Code Level Roma Populations across Greece}

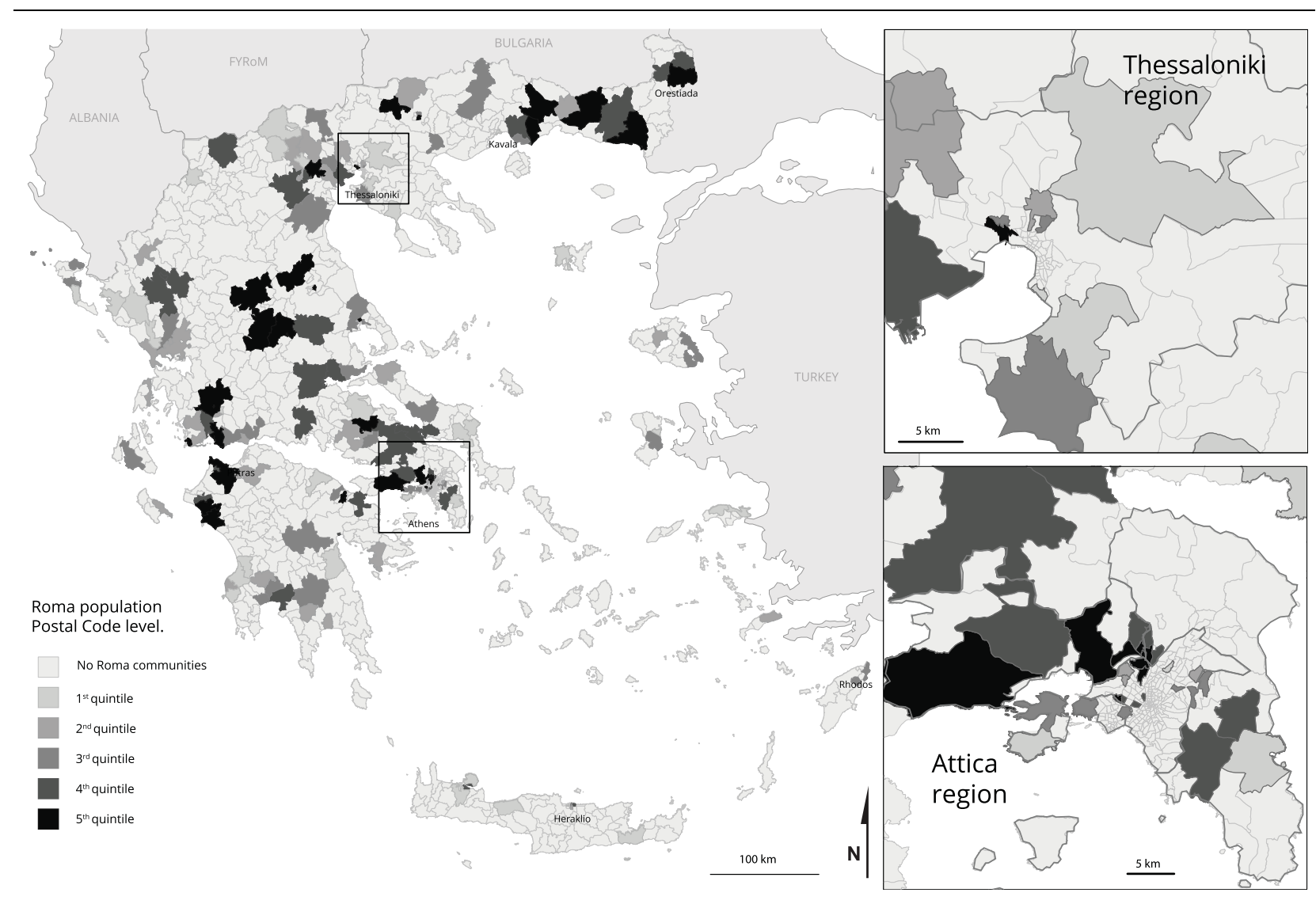

Note: This figure depicts Roma community populations aggregated to the zip code level. We can see that large Roma communities are more heavily concentrated in major urban areas.

effects of geographic proximity. In addition, we show that very small Roma communities do not seem to trigger racial threat, and can more tentatively suggest, based on the strong effects we detect near informal settlements, that racial threat is activated based on outgroup visibility. However, since our quantitative data do not speak to the nature of intergroup contact, we supplement our main analysis with semi-structured, in-depth interviews.

\section{QUALITATIVE ASSESSMENT OF GREEK- ROMA INTERGROUP CONTACT}

To better understand how intergroup contact in segregated settings influences donations to highly stigmatized groups, we interviewed principals from 12 public elementary schools that benefit from the school lunch program we fundraised for in this study. An experienced school coordinator conducted all the interviews; for details see Appendix V. We expected to observe the most positive, structured, and extensive intergroup contact in the elementary school setting because Roma school attendance drops significantly by middle school in Greece and throughout Europe (European Union Agency for Fundamental Rights 2014, 29-33). We selected schools from a wide range of communities that varied in terms of Roma integration and Roma socioeconomic status, ranging from communities characterized by extreme segregation and high levels of Roma poverty to those known for successful integration and relatively wealthy Roma communities (i.e., Agia Varvara). All selected schools had at least a few Roma students, but both the interviewer and the school principals had extensive experience with similar schools that had no Roma students, giving them a baseline understanding of these schools.

Our interview evidence confirms significant isolation and hostility toward the Roma across all communities. Even in the most integrated communities, positive interaction between ethnic Greeks and Roma were intermittent; in general, intergroup contact was rare. Despite widespread prejudice and limited contact, principals still reported that ethnic Greeks donated in-kind aid to segregated Roma schools due to perceived need. That said, most support came from national and international organizations.

Table 1 presents the 12 schools whose principals we interviewed, categorized by whether the community is near Roma settlements, neighborhoods, or both. The "Location" column indicates whether the community is urban, on the periphery of an urban area, or rural. The adjacent column "Roma student SE" specifies whether the majority of Roma students at the school have very 


\section{FIGURE 4. Predicted Probability of Donation to Greek Child, Child, and Roma Child Based on Proximity to Informal Roma Communities (with 95\% Cls)}

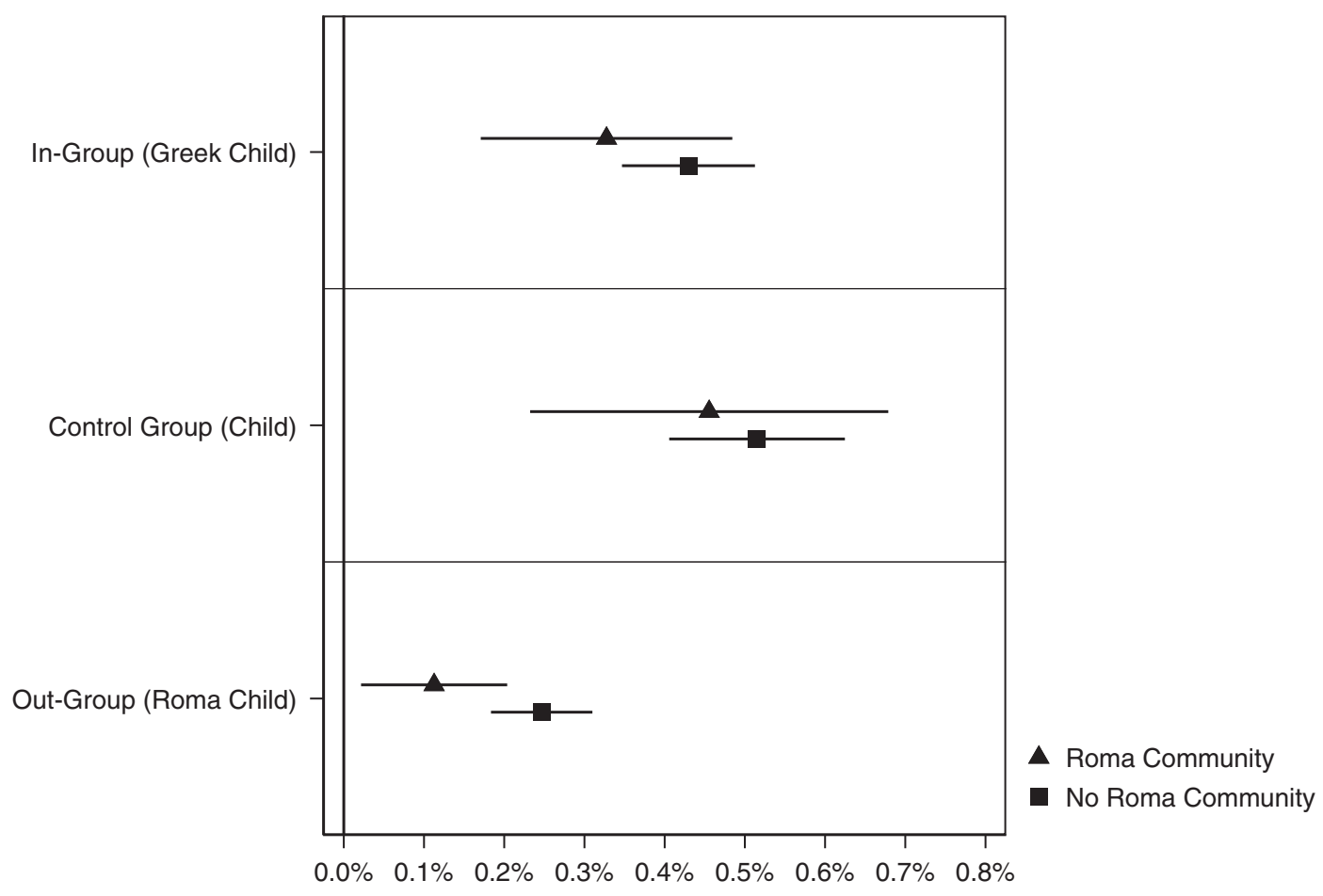

Note: Logistic regression predicting donation based on the three pooled treatments: In-Group (Greek Child), Control Group (Child), OutGroup (Roma Child), and proximity to the Roma (and their interaction term), with controls for age, gender, Attica, Central Macedonia, median income, percentage of children in poverty, and city size. Roma proximity is a function of zip code level Roma presence exceeding a population of 100 residents, with informal housing structures present. To see that these findings are robust without covariate adjustment and to other model specifications, see Appendix II, Figure II.2 and Table II.6. For additional specifications and robustness checks, please see Appendix II, Figures II.3 and II.4.

TABLE 1. Measures of Disadvantage and Levels of Segregation

\begin{tabular}{|c|c|c|c|c|c|}
\hline School name & Region & Location & Roma student SE & $\%$ Roma students & $\begin{array}{l}\text { Interactions } \\
\text { outside school }\end{array}$ \\
\hline \multicolumn{6}{|c|}{ Settlements only } \\
\hline School A & Thiva & Rural & Middle & $3 \%$ & Very Low \\
\hline School B & Thiva & Rural & Low & $100 \%$ & Very Low \\
\hline School A & Chalandri & Urban & Very Low & $5 \%$ & Very Low \\
\hline School B & Chalandri & Urban & Very Low & $7 \%$ & Very Low \\
\hline \multicolumn{6}{|c|}{ Settlements and neighborhoods } \\
\hline School A & Zefiri & Urban & Upper Middle & $5 \%$ & Very Low \\
\hline School B & Zefiri & Urban & Middle & $100 \%$ & Very Low \\
\hline School A & Megara & Urban & Middle & $15 \%$ & Very Low \\
\hline School B & Megara & Urban & Low & $38 \%$ & Very Low \\
\hline School A & Aspropirgos & Urban Periphery & Very Low & $74 \%$ & Very Low \\
\hline School B & Aspropirgos & Urban Periphery & Very Low & $95 \%$ & Moderate \\
\hline \multicolumn{6}{|c|}{ Neighborhoods only } \\
\hline School A & Agia Varvara & Urban & Middle & $35 \%$ & Moderate \\
\hline School B & Agia Varvara & Urban & Upper Middle & $64 \%$ & Moderate \\
\hline
\end{tabular}


TABLE 2. School Funding Sources

\begin{tabular}{|c|c|c|c|c|c|c|c|c|c|}
\hline $\begin{array}{l}\text { School } \\
\text { name }\end{array}$ & Region & $\begin{array}{l}\% \text { Roma } \\
\text { students }\end{array}$ & $\begin{array}{l}\text { Roma } \\
\text { students } \\
\text { have very } \\
\text { low SE }\end{array}$ & $\begin{array}{l}\text { Interactions } \\
\text { outside } \\
\text { school }\end{array}$ & EU & $\begin{array}{c}\text { Greek } \\
\text { Govt }\end{array}$ & NGO & Church & Community \\
\hline School A & Thiva & $3 \%$ & No & Very Low & & & Yes & & \\
\hline School A & Chalandri & $5 \%$ & Yes & Very Low & Yes & Yes & Yes & & \\
\hline School A & Zefiri & $5 \%$ & No & Very Low & & Yes & Yes & & \\
\hline School B & Chalandri & $7 \%$ & Yes & Very Low & Yes & Yes & Yes & & \\
\hline School A & Megara & $15 \%$ & No & Very Low & Yes & Yes & Yes & & \\
\hline School A & Agia Varvara & $35 \%$ & No & Moderate & & Yes & Yes & & \\
\hline School B & Megara & $38 \%$ & Yes & Very Low & Yes & Yes & Yes & Yes & \\
\hline School B & Agia Varvara & $64 \%$ & No & Moderate & Yes & Yes & Yes & & \\
\hline School A & Aspropirgos & $74 \%$ & Yes & Very Low & & Yes & Yes & & \\
\hline School B & Aspropirgos & $95 \%$ & Yes & Moderate & Yes & Yes & Yes & & Yes \\
\hline School B & Thiva & $100 \%$ & Yes & Very Low & Yes & Yes & Yes & Yes & Yes \\
\hline School B & Zefiri & $100 \%$ & No & Very Low & Yes & Yes & Yes & & Yes \\
\hline
\end{tabular}

low, low, middle, or upper-middle socioeconomic class status. The column "\% Roma students" illustrates the percentage of each school's student body that is Roma, and the final column estimates the extent of intergroup interactions outside of school. These last columns reflect the school principals' estimates. Appendix V contains detailed data underpinning these estimates.

We observe the most extreme segregation in Zefiri and Thiva, two communities where one school's student body is $100 \%$ Roma, while the neighboring school is only $3-5 \%$ Roma. Roma students' socioeconomic status and living conditions correlate with levels of integration. The handful of Roma students attending integrated schools are socioeconomically advantaged compared to their segregated school counterparts. For example, as Table V.1 in Appendix V shows, in Thiva's school B (100\% Roma student body), the majority of Roma live in the nearby informal settlement in makeshift housing that lacks running water and electricity. Conversely, the few Roma students that attend Thiva's school A are largely middle class and live in houses equipped with basic amenities.

Table 1 illustrates that ethnic Greek-Roma contact outside of school is very low across the board. Even in the most integrated communities where the majority of Roma live in neighborhoods alongside ethnic Greeks, principals reported only moderate levels of contact. For example, Agia Varvara is known as the best example of Roma integration. The majority of Roma students in both schools come from middle to upper-middle socioeconomic class backgrounds and live in houses or modern apartments in neighborhoods. While elementary school children invite the whole class to birthday parties and Greek and Roma boys play soccer together after school, Roma and Greek parents interact infrequently. Meanwhile, in highly segregated communities like Chalandri and Zefiri, social contact is even rarer. In Zefiri's school A (whose Roma students make up only $5 \%$ of the student body and are largely from middle-class backgrounds), the principal emphasized that Roma and Greek parents are "not hostile and say good morning at school." Appendix V, Table V.2 contains additional information indicating that across these communities, Roma-Greek contact is limited. Moreover, interview evidence in Appendix $\mathrm{V}$ indicates that Greek and Roma parents actively discourage their children from interacting.

We asked principals about additional support for school programming outside of the government funds provided to all public schools and listed these sources in Table 2. Almost all schools in the sample received financial support from the EU and the Greek government to provide extra classes aimed at helping struggling students, including English language instruction, hygiene and nutrition classes, and a variety of extracurricular activities like sports. The majority of schools received significant financial and programmatic support from international and national NGOs like the British Council, the International Red Cross, Solidarity Now, and Prolepsis.

Despite low levels of intergroup contact, principals in schools located next to informal Roma settlements reported that several ethnic Greeks in the local community donated in-kind goods such as clothing, shoes, food, pencils, and other school supplies (Zefiri school B; Thiva school B; and Aspropirgos school B). Ethnic Greeks were motivated to donate due to perceptions of need in impoverished local Roma communities.

In short, our interview evidence illustrates that Greek-Roma contact is very limited and often discouraged by both Greek and Roma communities. In addition, interviews in Appendix $\mathrm{V}$ demonstrate that ethnic Greeks stereotype the Roma as having low educational and labor force attainment. This suggests that the racial threat response we observe in our experiment is not explained by intergroup competition for economic or social status. Financial support for schools with many impoverished Roma students comes in part from local fundraising, but more commonly from national and European governmental and nongovernmental sources that draw on broader tax and donor bases. 


\section{CONCLUSIONS AND IMPLICATIONS}

We are the first to examine in-group preference and out-group bias in charitable giving in an increasingly common fundraising setting - the text-to-give campaign. Through an experiment embedded in a nationwide fundraising campaign, we find that an in-group appeal did not increase donations relative to our baseline, while an out-group appeal decreased donations by $50 \%$. We also find that an appeal to universal human rights - a common advocacy frame - did not reduce the generosity gap. Finally, we find that donations to all groups declined near Roma communities and declined disproportionately for the Roma appeal. Our qualitative research showed that Greek-Roma contact was limited, even in the most integrated communities. Most support for schools with Roma students came from outside the local community, although a few principals also obtained in-kind support locally by making needbased appeals.

Our findings have direct implications for NGOs as they identify ways to solicit support for stigmatized groups. Many NGOs emphasize in-group ties for fundraising (Koch et al. 2009), including shared religion or nationality (Kessler and Mummendey 2001; Lazarev and Sharma 2017), or seek to broaden the in-group to include all of humanity (Scroggins et al. 2016). Our empirical test of these strategies suggests that they may not work as expected. Future research should examine how context influences the efficacy of in-group and human rights appeals. Our key takeaway for NGOs is that a simple fundraising appeal emphasizing recipient needs without identifying the recipient's group membership facilitates fundraising for diverse beneficiaries.

By making appeals for three groups - the in-group, a control group, and the out-group-we are able to identify that out-group bias drives the in-group/outgroup donation differential in our study. Although the donations literature suggests that an in-group reference can foreground a responsibility to contribute (Bohm, Rusch, and Gurek 2016; Corr et al. 2015), we found no evidence of this in our experiment. It is possible that strong in-group bias - which lab and labin-the-field experiments tend to find-may be driven just as much by social desirability bias as is generosity toward out-groups in those same settings. Our finding suggests that theories of discrimination based entirely on rational in-group preference, which emphasize greater reciprocity (Habyarimana et al. 2007), greater trust (Alesina and La Ferrara 2002), and greater ability to control aid recipients within ethnic communities (Bowles and Gintis 2004; Miguel and Gugerty 2005), cannot fully account for gaps in public goods provision commonly observed in heterogeneous communities. We also find that an appeal to universal human rights does not persuade Greeks to donate more to the Roma. While human rights appeals may allow NGOs to raise awareness or shift public opinion for policy change, as prior research suggests (Chilton and Versteeg 2015; Gaertner and Dovidio 2014; Linos 2013), these appeals may be less useful as fundraising tools.
Our findings also shed light on contexts of extreme prejudice and segregation. In such settings, NGOs often exclude highly stigmatized groups from their programming, expecting fundraising to be impossible. For instance, flood operations in Malaysia have excluded the Rohingya minority (Desportes 2019), relief operations in Yemen have excluded the Al-Akhdam people of African descent (Housing and Land Rights Network 2006), and NGOs in Pakistan have excluded transgender individuals from their aid programs (Rumbach and Knight 2014). We found that even when appeals emphasized the Roma ethnicity of beneficiaries, some donations were still made both in the experiment and in our qualitative data. This suggests that fully excluding stigmatized out-groups is unnecessary. Moreover, since we found that an appeal for a child in need was as effective as an appeal for a Greek child in need, NGOs should consider broadbased fundraising appeals that allow for inclusive programming.

Relatedly, there is a widespread assumption in the political behavior literature that behavioral measures of out-group bias reveal more severe prejudice toward minority groups than attitudinal measures because people tend to conceal their prejudices in surveys (Crosby, Bromley, and Saxe 1980). However, EU surveys report similar rates of prejudice toward the Roma as does our behavioral donation measure-approximately 50\% (European Commission 2015). This suggests that the social desirability mechanisms that limit explicit discrimination toward some minorities may not operate for highly stigmatized groups. Given widespread prejudice, members of the ethnic majority may not gain social status by concealing negative views, leading explicit and implicit measures to converge on a similar estimate of bias. Future research could investigate whether a U-shaped relationship exists, in which implicit and explicit discrimination measures coincide when explicit prejudice is both very high and very low - but not moderate - in magnitude.

Consistent with racial threat theories, we find that donations decline in proximity to informal Roma settlements. Our experimental design allows us to add to a large observational literature that observes similar declines and to distinguish between a general decline in donations to all groups (which we also observed) and a greater, targeted decline that only occurs in the Roma appeal condition.

At the same time, our study also invites further research on the scope conditions and mechanisms underlying racial threat theory. The out-group we study is not in direct competition with the dominant group over social and economic status and resources, and so this mechanism cannot explain why we find evidence of racial threat in our donation experiment (Jackson 1986; Wetts and Willer 2018). Our qualitative evidence also indicates that while ethnic Greeks express a wide variety of concerns about the Roma, competition for resources does not figure prominently in these narratives. In addition, ethnic Greeks rarely engage in meaningful social contact with the Roma. In societies in which ethnic minorities are physically segregated from 
majority populations, as in the case of the Roma living in settlements across Europe, the Rohingya living in camps in India and Bangladesh, or the Uyghur Muslims in China, we need more research on how and when racial threat operates.

Our proximity analysis demonstrates that the presence of stigmatized groups above a low population threshold may trigger a racial threat response in nearby residents. Our strongest evidence of racial threat is in proximity to informal Roma communities. We believe this may be because makeshift housing and extreme poverty further highlight intergroup differences in economic and cultural attributes. Recent work by Enos (2016) moves us forward on theorizing the effects of minority housing in the United States, but research elsewhere is scarce.

Finally, we expect that scholars can easily extend our unobtrusive, low-cost text message intervention to a wide variety of contexts, adding to the external validity and generalizability of research on public goods provision, altruism, and group bias. Since mobile phones are ubiquitous across high, middle, and low-income countries, text-to-give campaigns allow NGOs to appeal to broad audiences (Chen and Givens 2013; Smith 2012). We believe scholars can also use text message appeals to measure a wide range of theories related to social, civic, economic, and political development. Already, important work examines how text message reminders increase voter turnout (e.g., Dale and Strauss 2009) and reports of public service deficiencies to politicians (e.g., Grossman, Michelitch, and Santamaria 2017). Because textto-give campaigns typically aim at raising awareness and funds, future research should examine how the same reminder influences different attitudinal and behavioral measures (e.g., self-reported beliefs, financial contributions, willingness to sign a petition, contact a politician, or contribute to integration programming like language lessons). Future studies conducted in the text-to-give context will not only shed light on this increasingly important tool for fundraising and mobilization but also rigorously test and refine theories that are dependent on institutional and contextual factors.

\section{SUPPLEMENTARY MATERIALS}

To view supplementary material for this article, please visit http://dx.doi.org/10.1017/S0003055420000787.

Replication materials can be found on Dataverse at: https://doi.org/10.7910/DVN/2XO7HR.

\section{REFERENCES}

Adida, Claire L., David D. Laitin, and Marie-Anne Valfort. 2010. "Identifying Barriers to Muslim Integration in France." Proceedings of the National Academy of Sciences 107 (52): 22384-90.

Adida, Claire L., David D. Laitin, and Marie-Anne Valfort. 2016.

"“One Muslim is Enough!' Evidence from a Field Experiment in France." Annals of Economics and Statistics 121-122: 121-60.
Alesina, Alberto, and Eliana La Ferrara. 2000. "Participation in Heterogeneous Communities." The Quarterly Journal of Economics 115 (3): 847-904.

Alesina, Alberto, and Eliana La Ferrara. 2002. "Who Trusts Others?" Journal of Public Economics 85 (2): 207-34.

Alexander, Marcus, and Fotini Christia. 2011. "Context Modularity of Human Altruism." Science 334 (6061): 1392-4.

Allport, Gordon.W. 1954. The Nature of Prejudice. New York: Perseus Books Publishing.

Amirkhanian, Yuri A., Jeffrey A. Kelley, Eric G. Benotsch, Anton M. Somlai, Kevin D. Brown, María Isabel Fernández, and Karen M. Opgenorth. 2004. "HIV Prevention Nongovernmental Organizations in Central and Eastern Europe: Programs, Resources and Challenges." Central European Journal of Public Health 12 (1): 12-8.

Ayres, Ian, Fredrick E. Vars, and Nasser Zakariya. 2004. "To Insure Prejudice: Racial Disparities in Taxicab Tipping." Yale Law Journal 114: 1613-74.

Ball, Stephen J. 2007. Education Plc: Understanding Private Sector Participation in Public Sector Education. London: Routledge.

Banerjee, Rupa. 2008. "An Examination of Factors Affecting Perception of Workplace Discrimination." Journal of Labor Research 29 (4): 380-401.

Basok, Tanya, and Emily Carasco. 2010. "Advancing the Rights of Non-citizens in Canada: A Human Rights Approach to Migrant Rights." Human Rights Quarterly 32 (2): 342-66.

Batson, Daniel, David Lishner, and Eric Stocks. 2015. "The Empathy-Altruism Hypothesis." In The Oxford Handbook of Prosocial Behavior, eds. David Schroeder and William Graziano, 259-68. New York: Oxford University Press.

Bekkers, René, and Pamala Wiepking. 2011. "A Literature Review of Empirical Studies of Philanthropy: Eight Mechanisms that Drive Charitable Giving." Nonprofit and Voluntary Sector Quarterly 40 (5): 924-73.

Belcher, John R., and Bruce R. DeForge. 2012. "Social Stigma and Homelessness: The Limits of Social Change." Journal of Human Behavior in the Social Environment 22 (8): 929-46.

Bloemraad, Irene, Fabiana Silva, and Kim Voss. 2016. "Rights, Economics, or Family? Frame Resonance, Political Ideology, and the Immigrant Rights Movement." Social Forces 94 (4): 1647-74.

Bob, Clifford. 2007. "Dalit Rights are Human Rights: Caste Discrimination, International Activism, and the Construction of a New Human Rights Issue." Human Rights Quarterly 29 (1): 167-93.

Bobo, Lawrence. 1983. "Whites' Opposition to Busing: Symbolic Racism or Realistic Group Conflict?" Journal of Personality and Social Psychology 45 (6): 1196-260.

Bohm, Robert, Hannes Rusch, and Ozgur Gurerk. 2016. "What Makes People Go to War? Defensive Intentions Motivate Retaliatory and Preemptive Intergroup Aggression." Evolution and Human Behavior 37 (1): 29-34.

Booth, Alison L., Andrew Leigh, and Elena Varganova. 2012. "Does Ethnic Discrimination Vary across Minority Groups? Evidence from a Field Experiment." Oxford Bulletin of Economics and Statistics 74 (4): 547-73.

Bowles, Samuel, and Herbert Gintis. 2004. "The Evolution of Strong Reciprocity: Cooperation in Heterogeneous Populations." Theoretical Population Biology 65 (1): 17-28.

Bracic, Ana. 2016. "Reaching the Individual: EU Accession, NGOs, and Human Rights." American Political Science Review 110 (3): 530-46.

Brewer, Marilynn B., and Samuel L. Gaertner. 2003. "Toward Reduction of Prejudice: Intergroup Contact and Social Categorization.” In Blackwell Handbook of Social Psychology: Intergroup Processes, eds. Rupert Brown and Samuel Gaertner, 451-72. Malden, MA: Blackwell Publishers.

Brown, Rupert, and Miles Hewstone. 2005. "An Integrative Theory of Intergroup Contact." Advances in Experimental Social Psychology 37: 255-343.

Buchan, Nancy R., Marilynn B. Brewer, Gianluca Grimalda, Rick K. Wilson, Enrique Fatas, and Margaret Foddy. 2011. "Global Social Identity and Global Cooperation." Psychological Science 22 (6): $821-8$.

Carlson, Melissa, Laura Jakli, and Katerina Linos. 2017. "Refugees Misdirected: How Information, Misinformation, and Rumors 
Shape Refugees' Access to Fundamental Rights." Virginia Journal of International Law 57 (3): 539-74.

Carlson, Melissa, Laura Jakli, and Katerina Linos. 2018. "Rumors and Refugees: How Government-Created Information Vacuums Undermine Effective Crisis Management.” International Studies Quarterly 62 (3): 671-85.

Caprioni, Elena. 2011. "Daily Encounters Between Hans and Uyghurs in Xinjiang: Sinicization, Integration or Segregation?" Pacific Affairs 84 (2): 267-87.

Chen, Wenhong, and Travis Givens. 2013. "Mobile Donation in America." Mobile Media and Communication 1 (2): 196-212.

Chilton, Adam S., and Mila Versteeg. 2015. "The Failure of Constitutional Torture Prohibitions." The Journal of Legal Studies 44 (2): 417-52.

Condra, Luke N., and Sera Linardi. 2019. "Casual Contact and Ethnic Bias: Experimental Evidence from Afghanistan." The Journal of Politics 81 (3): 1028-42.

Coppock, Alexander. 2019. "Avoiding Post-Treatment Bias in Audit Experiments." Journal of Experimental Political Science 6 (1): 1-4.

Corr, Philip J., Shaun P. Hargreaves Heap, Charles R. Seger, and Kei Tsutsui. 2015. "An Experiment on Individual 'Parochial Altruism:' Revealing No Connection between Individual 'Altruism' and Individual 'Parochialism.'” Frontiers in Psychology 6: 1261.

Cortes, Ismael. 2015. "Interview with Zeljko Jovanovic, Director of the Roma Initiatives Office at the Open Society Foundations." Romea.cz. http://romea.cz/en/features-and-commentary/ interviews/interview-with-zeljko-jovanovic-director-of-the-romainitiatives-office-at-the-open-society-foundations.

Cottrell, Catherine A., and Steven L. Neuberg. 2005. "Different Emotional Reactions to Different Groups: A Socio-Functional Threat-Based Approach to Prejudice." Journal of Personality and Social Psychology 88 (5): 770-89.

Cretan, Remus, and Ryan Powell. 2018. "The Power of Group Stigmatization: Wealthy Roma, Urban Space and Strategies of Defense in Post-Socialist Romania." International Journal of Urban and Regional Research 42 (3): 423-41.

Crosby, Faye, Stephanie Bromley, and Leonard Saxe. 1980. "Recent Unobtrusive Studies of Black and White Discrimination and Prejudice: A Literature Review." Psychological Bulletin 87 (3) 546-63.

Dale, Allison, and Aaron Strauss. 2009. "Don't Forget to Vote: Text Message Reminders as a Mobilization Tool." American Journal of Political Science 53 (4): 787-804.

Damgaard, Mette Trier, and Christina Gravert. 2017. "Now or Never! The Effect of Deadlines on Charitable Giving: Evidence from Two Natural Field Experiments." Journal of Behavioral and Experimental Economics 66: 78-87.

Deshpande, Ashwini, and Dean Spears. 2016. "Who is the Identifiable Victim? Caste and Charitable Giving in Modern India." Economic Development and Cultural Change 64 (2): 299-321.

Desportes, Isabelle. 2019. "Getting Relief to Marginalised Minorities: The Response to Cyclone Komen in 2015 in Myanmar." Journal of International Humanitarian Action 4 (1): $1-16$

Diller, Matthew. 2001. "Form and Substance in the Privatization of Poverty Programs." UCLA Law Review 49: 1739-58.

Eckel, Catherine, Philip Grossman, and Angela Milano. 2007. "Is More Information Always Better? An Experimental Study of Charitable Giving and Hurricane Katrina." Southern Economic Journal 74 (2): 388-411.

Eitle, David, and R. Jay Turner. 2002. "Exposure to Community Violence and Young Adult Crime: The Effects of Witnessing Violence, Traumatic Victimization, and Other Stressful Life Events." Journal of Research in Crime and Delinquency 39 (2): 214-37.

Enos, Ryan D. 2014. "Causal Effect of Intergroup Contact on Exclusionary Attitudes." Proceedings of the National Academy of Sciences 111 (10): 3699-704.

Enos, Ryan D. 2016. "What the Demolition of Public Housing Teaches Us about the Impact of Racial Threat on Political Behavior." American Journal of Political Science 60 (1): 123-42.

Enos, Ryan D., and Noam Gidron. 2016. "Intergroup Behavioral Strategies as Contextually Determined: Experimental Evidence from Israel." The Journal of Politics 78 (3): 851-67.
Enos, Ryan D., and Noam Gidron. 2018. "Exclusion and Cooperation in Diverse Societies: Experimental Evidence from Israel." American Political Science Review 112 (4): 742-57.

European Commission. 2015. "Special Eurobarometer 437. Discrimination in the EU in 2015." Luxembourg: DirectorateGeneral for Communication. http://ec.europa.eu/ COMMFrontOffice/publicopinion/index.cfm/Survey/ getSurveyDetail/instruments/SPECIAL/surveyKy/2077.

EU-MIDIS II (European Union Agency for Fundamental Rights). 2014. "Education: The Situation of Roma in 11 EU Member States." Vienna: EU-MIDIS II. https://fra.europa.eu/sites/default/files/fra2014_roma-survey_education_tk0113748enc.pdf.

EU-MIDIS II (European Union Agency for Fundamental Rights). 2016. Second European Union Minorities and Discrimination Survey Roma-Selected findings. Vienna: EU-MIDIS II. http:// fra.europa.eu/en/publication/2016/eumidis-ii-roma-selectedfindings.

Fong, Christina M., and Erzo F. P. Luttmer. 2011. "Do Fairness and Race Matter in Generosity? Evidence from a Nationally Representative Charity Experiment." Journal of Public Economics 95 (5-6): 372-94.

Fossett, Mark A., and K. Jill Kiecolt. 1989. "The Relative Size of Minority Populations and White Racial Attitudes." Social Science Quarterly 70 (4): 820-35.

Gaertner, Samuel L., and John F. Dovidio. 2014. Reducing Intergroup Bias: The Common Ingroup Identity Model. New York: Psychology Press.

Gerdes, Christer. 2011. "The Impact of Immigration on the Size of Government: Empirical Evidence from Danish Municipalities." Scandinavian Journal of Economics 113 (1): 74-92.

Grossman, Guy, Kristin Michelitch, and Marta Santamaria. 2017. "Texting Complaints to Politicians: Name Personalization and Politicians' Encouragement in Citizen Mobilization." Comparative Political Studies 50 (10): 1325-57.

Ha, Shang E., and Dean S. Karlan. 2009. "Get-Out-The-Vote Phone Calls: Does Quality Matter?" American Politics Research 37 (2): 353-69.

Habyarimana, James, Macartan Humphreys, Daniel N. Posner, and Jeremy M. Weinstein. 2007. "Why Does Ethnic Diversity Undermine Public Goods Provision?" American Political Science Review 101 (4): 709-25.

Hafer, Carolyn L. 2011. "The Psychology of Deservingness and Acceptance of Human Rights." In Justice and Conflicts, eds. Elisabeth Kals and Jurgen Maes, 407-27. Heidelberg: Springer.

Halevy, Nir, Gary Bornstein, and Lilach Sagiv. 2008. "In-group Love' and 'Out-group Hate' as Motives for Individual Participation in Intergroup Conflict: A New Game Paradigm.” Psychological Science 19 (4): 405-11.

Hardin, Garrett. 1995. Living within Limits: Ecology, Economics, and Population Taboos. Oxford: Oxford University Press.

Harrison, Glenn W., and John A. List. 2004. "Field Experiments." Journal of Economic Literature 42 (4): 1009-55.

Hellenic Statistical Authority. 2014. "Demographic and Social Characteristics of the Resident Population of Greece According to the 2011 Population-Housing Census Revision of 20/3/2014." Hellenic Statistical Authority. http://statistics.gr/en/2011-censuspop- hous.

Henry, P. J., Christine Reyna, and Bernard Weiner. 2004. "Hate Welfare but Help the Poor: How the Attributional Content of Stereotypes Explains the Paradox of Reactions to the Destitute in America." Journal of Applied Social Psychology 34 (1): 34-58.

Hopkins, Nick. 2011. "Dual Identities and their Recognition: Minority Group Members' Perspectives.” Political Psychology 32 (2): 251-70

Housing and Land Rights Network. 2006. "The Human Right to Adequate Housing in the case of al-Akhdam (Yemen)." Habitat International Coalition. https://hlrn.org/publication_det.php?id=02hs.

Ivarsflaten, Elisabeth, and Paul M. Sniderman. 2017. "The Challenge of Muslim Inclusion.” DIGSSCORE Working Paper Series 7. https://www.uib.no/sites/w3.uib.no/files/attachments/working paper_2017-7.pdf.

Jackson, Pamela I. 1986. "Black Visibility, City Size, and Social Control." The Sociological Quarterly 27 (2): 185-203.

Kessler, Thomas, and Amélie Mummendey. 2001. "Is there Any Scapegoat Around? Determinants of Intergroup Conflicts at 
Different Categorization Levels." Journal of Personality and Social Psychology 81 (6): 1090-102.

Kinder, Donald, and David Sears. 1981. "Prejudice and Politics: Symbolic Racism versus Racial Threats to the Good Life." Journal of Personality and Social Psychology 40 (3): 414-31.

King, Ryan, and Darren Wheelock. 2007. "Group Threat and Social Control: Race, Perceptions of Minorities and the Desire to Punish." Social Forces 85 (3): 1255-80.

Kipgen, Nehginpao. 2013. "Conflict in Rakhine State in Myanmar: Rohingya Muslims' Conundrum.” Journal of Muslim Minority Affairs 33 (2): 298-310.

Koch, Dirk-Jan, Axel Dreher, Peter Nunnenkamp, and Rainer Thiele. 2009. "Keeping a Low Profile: What Determines the Allocation of Aid by Non-Governmental Organizations?" World Development 37 (5): 902-18.

Kogut, Tehila, and Ilana Ritov. 2011. "The Identifiable Victim Effect: Causes and Boundary Conditions." In The Science of Giving: Experimental Approaches to the Study of Charity, eds. Daniel M. Oppenheimer and Christopher Y. Olivola, 133-48. New York: Psychology Press.

Kogut, Tehila, and Ilana Ritov. 2007. "One of Us: Outstanding Willingness to Help Save a Single Identified Compatriot." Organizational Behavior and Human Decision Processes 104 (2): 150-7.

Korpi, Walter, and Joakim Palme. 2003. "New Politics and Class Politics in the Context of Austerity and Globalization: Welfare State Regress in 18 Countries, 1975-95." American Political Science Review 97 (3): 425-46.

Larsen, Christian Albrekt, and Thomas Engel Dejgaard. 2013. "The Institutional Logic of Images of the Poor and Welfare Recipients: A Comparative Study of British, Swedish and Danish Newspapers." Journal of European Social Policy 23 (3): 287-99.

Lazarev, Egor, and Kunaal Sharma. 2017. "Brother or Burden: An Experiment on Reducing Prejudice toward Syrian Refugees in Turkey." Political Science Research and Methods 5 (2): 201-19.

Lee, Alexander. 2018. "Ethnic Diversity and Ethnic Discrimination: Explaining Local Public Goods Provision." Comparative Political Studies 51 (10): 1351-83.

Lerche, Jens. 2008. "Transnational Advocacy Networks and Affirmative Action for Dalits in India." Development and Change 39 (2): 239-61.

Linos, Katerina. 2003. "Understanding Greek Immigration Policy." In New Approaches to Balkan Studies, ed. Dimitris Keridis, 309-44. Dulles, VA: Brassey's.

Linos, Katerina, and Martin R. West. 2003. "Self-Interest, Social Beliefs, and Attitudes to Redistribution: Re-addressing the Issue of Cross-National Variation." European Sociological Review 19 (4): 393-409.

Linos, Katerina. 2011. "Diffusion through Democracy." American Journal of Political Science 55 (3): 678-95.

Linos, Katerina. 2013. The Democratic Foundations of Policy Diffusion: How Health, Family, and Employment Laws Spread across Countries. Oxford: Oxford University Press.

Luttmer, Erzo F. 2001. "Group Loyalty and the Taste for Redistribution." Journal of Political Economy 109 (3): 500-28.

Matin, Imran, and David Hulme. 2003. "Programs for the Poorest: Learning from the IGVGD Program in Bangladesh." World Development 31 (3): 647-65.

Matras, Yaron. 2015. The Romani Gypsies. Cambridge, MA: Harvard University Press.

McEntire, Kyla, Michele Leiby, and Matthew Krain. 2015. "How to Ask People for Change: Examining Peoples' Willingness to Donate to Human Rights Campaigns." In The Social Practice of Human Rights, ed. Joel Pruce, 43-62. New York: Palgrave Macmillan.

McFarland, Sam, Matthew Webb, and Derek Brown. 2012. "All Humanity is My Ingroup: A Measure and Studies of Identification with All Humanity." Journal of Personality and Social Psychology 103 (5): 830-53.

McLaren, Lauren M. 2003. "Anti-Immigrant Prejudice in Europe: Contact, Threat Perception, and Preferences for the Exclusion of Migrants." Social Forces 81 (3): 909-36.

Miguel, Edward. 1999. "Ethnic Diversity, Mobility and School Funding: Theory and Evidence from Kenya." Unpublished Manuscript. Harvard University. http://eprints.1se.ac.uk/6675/1/ Ethnic_Diversity\%2C_Mobility_and_School_Funding_Theory_ and_Evidence_From_Kenya.pdf.
Miguel, Edward, and Mary Kay Gugerty. 2005. "Ethnic Diversity, Social Sanctions, and Public Goods in Kenya." Journal of Public Economics 89 (11): 2325-68.

Morrison, Kimberly Rios, Victoria C. Plaut, and Oscar Ybarra. 2010. "Predicting Whether Multiculturalism Positively or Negatively Influences White Americans' Intergroup Attitudes: The Role of Ethnic Identification." Personality and Social Psychology Bulletin 36: 1648-61.

Muslim Aid. 2020. "Water for All.” Muslim Aid. https:// muslimaid.org/water/.

Nickerson, Mike, and Winnifred Louis. 2008. "Nationality versus Humanity? Personality, Identity, and Norms in Relation to Attitudes toward Asylum Seekers." Journal of Applied Social Psychology 38 (3): 796-817.

Nickerson, Mike, and John A. List. 2007. "Does Price Matter in Charitable Giving? Evidence from a Large-Scale Natural Field Experiment.” The American Economic Review 97 (5): 1774-93.

Okten, Cagla, and Una Okonkwo Osili. 2004. "Contributions in Heterogeneous Communities: Evidence from Indonesia." Journal of Population Economics 17 (4): 603-26.

Persico, Nicola, and Dan Silverman. 2006. "Other-Regarding Behavior: Theories and Evidence." Unpublished Manuscript. University of Pennsylvania. https://economics.sas.upenn.edu/sites/ default/files/filevault/event_papers/Empirical100520060.pdf.

Pettigrew, Thomas F. 1998. "Intergroup Contact Theory." Annual Review of Psychology 49 (1): 65-85.

Putnam, Robert. 2007. "E Pluribus Unum: Diversity and Community in the Twenty-First Century: The 2006 Johan Skytte Prize Lecture." Scandinavian Political Studies 30 (2): 137-74.

Quillian, Lincoln. 1995. "Prejudice as a Response to Perceived Group Threat: Population Composition and Anti-immigrant and Racial Prejudice in Europe." American Sociological Review 60 (4): 586-611.

Reese, Gerhard, Jutta Proch, and Christine Finn. 2015. "Identification with All Humanity: The Role of Self-definition and Self-Investment." European Journal of Social Psychology 45 (4): 426-40.

Reilly, Niamh. 2007. "Linking Local and Global Feminist Advocacy: Framing Women's Rights as Human Rights in the Republic of Ireland." Women's Studies International Forum 30 (2): 114-33

Reysen, Stephen, and Iva Katzarska-Miller. 2013. "A Model of Global Citizenship: Antecedents and Outcomes." International Journal of Psychology 48 (5): 858-70.

Rumbach, Jennifer, and Kyle Knight. 2014. "Sexual and Gender Minorities in Humanitarian Emergencies." In Issues of Gender and Sexual Orientation in Humanitarian Emergencies, ed. Larry Roeder, 33-74. Cham, Switzerland: Springer.

Sambanis, Nicholas, Anna Schultz, and Elena Nikolova. 2018. "Austerity as Violence: Measuring the Effects of Economic Austerity on Pro-Sociality." Unpublished Manuscript. https:// bg.uek.krakow.p1/e-zasoby/siec_lokalna/Ebor/w220.pdf.

Scacco, Alexandra, and Shana S. Warren. 2018. "Can Social Contact Reduce Prejudice and Discrimination? Evidence from a Field Experiment in Nigeria." American Political Science Review 112 (3): 654-77.

Scroggins, W. Anthony, Diane M. Mackie, Thomas J. Allen, and Jeffrey W. Sherman. 2016. "Reducing Prejudice with Labels: Shared Group Memberships Attenuate Implicit Bias and Expand Implicit Group Boundaries." Personality and Social Psychology Bulletin 42 (2): 219-29.

Shier, Micheal L., and Femida Handy. 2012. "Understanding Online Donor Behavior: The Role of Donor Characteristics, Perceptions of the Internet, Website and Program, and Influence from Social Networks." International Journal of Nonprofit and Voluntary Sector Marketing 17 (3): 219-30.

Singh, Prerna, and Matthias vom Hau. 2016. "Ethnicity in Time: Politics, History, and the Relationship between Ethnic Diversity and Public Goods Provision." Comparative Political Studies 49 (10): $1303-40$.

Sim, Amy. 2003. "Organising Discontent: NGOs for Southeast Asian Migrant Workers in Hong Kong." Asian Journal of Social Science 31 (3): 478-510.

Smith, Aaron. 2012. "Real Time Charitable Giving." Washington, DC: Pew Internet and American Life Project. https://brandeis.edu/ 
investigate/political-social-justice/docs/real-time-charitablegiving-berkman.pdf.

Stichnoth, Holger, and Karine van der Straeten. 2013. "Ethnic Diversity, Public Spending, and Individual Support for the Welfare State: A Review of the Empirical Literature." Journal of Economic Surveys 27 (2): 364-89.

Stroschein, Sherrill. 2002. "NGO Strategies for Hungarian and Roma Minorities in Central Europe." Voluntas: International Journal of Voluntary and Nonprofit Organizations 13 (1): 1-26.

Tajfel, Henri. 1974. "Social Identity and Intergroup Behaviour." Social Science Information 13 (2): 65-93.

UNICEF (2020). "Education Program.” United Nations Children's Fund. https://unicef.org/education.

van der Waal, Jeroen, Peter Achterberg, Dick Houtman, Willem De Koster, and Katerina Manevska. 2010. "'Some are More Equal than Others': Economic Egalitarianism and Welfare Chauvinism in the Netherlands." Journal of European Social Policy 20 (4): 350-63.

Vigdor, Jacob L. 2004. "Community Composition and Collective Action: Analyzing Initial Mail Response to the 2000 Census." Review of Economics and Statistics 86 (1): 303-12.
Wagner, Ulrich, Oliver Christ, Thomas F. Pettigrew, Jost Stellmacher, and Carina Wolf. 2006. "Prejudice and Minority Proportion: Contact Instead of Threat Effects." Social Psychology Quarterly 69 (4): 380-90.

Wallace, Geoffrey P. R. 2013. "International Law and Public Attitudes toward Torture: An Experimental Study." International Organization 67 (1): 105-40.

Wetts, Rachel, and Robb Willer. 2018. "Privilege on the Precipice: Perceived Racial Status Threats Lead White Americans to Oppose Welfare Programs." Social Forces 97 (2): 793-822.

Winterich, Karen Page, Vikas Mittal, and William T. Ross Jr. 2009. "Donation Behavior toward In-groups and Out-groups: The Role of Gender and Moral Identity." Journal of Consumer Research 36 (2): 199-214

World Bank. 2018. "Mobile Cellular Subscriptions (per 100 People) European Union, Croatia.." International Telecommunication Union, World Telecommunication/ICT Development Report and database. https://data.worldbank.org/indicator/IT.CEL.SETS.P2? locations=EU-HR

Zizzo, Daniel John. 2010. "Experimenter Demand Effects in Economic Experiments." Experimental Economics 13 (1): 75-98. 